UDC 10.01 .00

DOI 10.23951/1609-624X-2021-3-135-145

\title{
SPATIAL MOBILITY AND SPIRITUAL OSCILLATIONS: ESTRANGEMENT OF DIASPORIC FEMALES IN MULBERRY AND PEACH AND SEARCHING FOR SYLVIE LEE'
}

\author{
Zhao Dongxu \\ Jilin Institute of Chemical Technology, China
}

\begin{abstract}
Introduction. The problems of awareness of life difficulties, psychological needs and anxieties of women of the Asian diaspora, as well as their survival strategies are studied.

Material and methods. This paper takes a comparative literature approach and textual close reading methods to interpret two novels written by Chinese overseas female writers.

Results and discussion. Both Nieh Hualing's Mulberry and Peach (1981) and Jean Kwok's Searching for Sylvie Lee (2019) depict the diasporic experiences of female fictional characters in war times and peaceful contemporary era respectively. Even if the dates of publication of the two novels are across nearly half a century, there are a number of identical elements between them. For instance, both female protagonists suffer from constant cross-border movements, estrangement, even schizophrenia. This paper endeavors to tackle the problems that firstly why female diasporas fall into the estrangement predicament through ceaseless transnational movements, then what are the dialectical relations of spatial mobility and estrangement, and lastly how and why they forge the alternating personality and fluid identity.

Conclusion. Through analysis, it concludes that the ceaseless spatial mobility experiences prompt the diasporic protagonists to estrange from their family, culture and self. Furthermore, spatial mobility and estrangement interplay between each other, and finally leading to diasporic women's dual personalities, which can be seen as both the predicament and the survival strategies of those diasporas. That is to say, the flexible and fluid personality or identity is a request for them to survive in foreign countries. It is hoped that the discussion on those protagonists' survival tactics will shed light on the exploration of the possible strategies to better the diasporas' living conditions.
\end{abstract}

Key words: estrangement, diasporic females, mobility.

\section{Introduction}

It's common to see bustling people hurrying in the busy street or time-starved passengers walking rapidly at the airport, preoccupied with their forthcoming destinations. The constant spatial mobility gradually becomes the main melody of the modern world as well as the thematic concern in the literature world since the $20^{\text {th }}$ century. "Mobility is often associated with ideas of freedom and self-realization. Yet immigrants' tales can uncover a dark, alienating side of mobility" [1, p. 1]. Double edges of mobility are presented in both the freedom and alienation that it brings to the subject. As for diasporas, "mobility is usually associated with subjugation, coercion, the impossibility of fulfillment for self or community - in short, Necessity" [2]. And according to the new mobilities paradigm, the compelled mobility represents the immobility of the subject since he/she is unable to control his/her actions.

In a sense, the spatial movements probably cause spiritual oscillations and estrangement of the subjects because of the departure from families, familiar environment and original cultures. Such disordered mental state is prominently embodied in the subordinate groups, such as females, immigrants, children, etc. Diasporic females have always been positioned in the in- ferior or marginal place in the family and in society. Their constant cross-border experience and identity crisis become the dominant themes of many Asian emigrant female writers since the late $20^{\text {th }}$ century. Maxine Hong Kingston's The Woman Warrior (1976), Amy Tan's The Joy Luck Club (1989), Kiran Desai's The Inheritance of Loss (2006), Celeste Ng's Everything I Never Told You (2014), taking a few as examples, narrate the diasporic experiences of females and render voice to those long-term silent diasporic subjects telling their poignant lives as well as psychological turmoil.

According to Nina Glick Schiller, transnationalism refers to "the process by which immigrants forge and sustain simultaneous multi-stranded social relations that link together their societies of origin and settlement" [3]. Undoubtedly, the transnational mobility of immigrants prompts the development of globalization and interaction among different races. As the intermediaries, especially people from the subordinating cultural background, diasporas commonly experience racial discrimination, poverty, acculturative stress and identity crisis in the host country. Most of all, the mobility life of separation from ones' homeland could make diasporas involve in mental isolation and estrangement. The estrangement from family sometimes

\footnotetext{
${ }^{1}$ Fund Projects: Jilin Institute of Chemical Technology Major scientific research projects "Research on Contemporary American Minority Women's Literature from the Perspective of Space Criticism (2019-2025)".
} 
may lead them to have hallucinations, dual personality, or even schizophrenia. Thus, this paper endeavors to examine the estrangement of diasporic female characters in Nieh Hualing's Mulberry and Peach [4] and the recently published novel Searching for Sylvie Lee [5] by Jean Kwok, aiming to tackle the following problems: firstly, why female diasporas fall into the estrangement predicament through ceaseless transnational movements; then, what the dialectical relations of spatial mobility and estrangement are, and lastly, how and why they forge the alternating personality and fluid identity.

Before tackling those questions, the background of the authors and novels will be presented. Both Nieh Hualing (1925- ) and Jean Kwok (1968- ) are Chinese emigrant female writers. Nieh Hualing is the founder of the well-known International Writing Program along with her husband Paul Engle [6]. As the most influential Chinese female writer, she was nominated for the Nobel Peace Prize in 1976. In her documentary, she summed up her life by saying, "I am a tree with roots in China, branches in Taiwan and leaves in Iowa." Her novel Mulberry and Peach is a semi-autobiography work, vividly and dramatically recording a diasporic lady's exile life.

Jean Kwok is the New York Times best-selling contemporary author who worked as an English teacher, a ballroom dancer, a dishwasher, and a computer graphics specialist before. The variety of working experience provides her with multiple resources for writing. Her latest novel Searching for Sylvie Lee is also well received as her previous two novels, Girl in Translation (2010) and Mambo in Chinatown (2010). It became the instant New York Times bestseller in the summer of 2019.

The protean nature of the protagonists in both works initially inspires me to connect the two novels. Obedient Mulberry in Mulberry and Peach has suffered a series of persecutions, eventually splitting into aggressive and carefree Peach. Similarly, Sylvie, the protagonist in Searching for Sylvie Lee, owns a dual personality presented in the Netherlands and in America separately. The similar fate of the heroines correlates these two works.

In addition to characterization, post-modern writing techniques are the two authors' common choices. As Grazia Micheli states that ethnic writers utilized "modernist and postmodernist literary devices to create fragmentary and heterogeneous texts, which are particularly suited to give voice to the equally fragmented, plural subjectivities of immigrants and their descendants" [1, p. 3]. Nieh and Kwok both utilize the post-modern technique of pastiche, composing their novels with diaries, news, letters or e-mails, telephone calls, etc. And the alternating narratives of Mulberry and Peach in Mulberry and Peach, Sylvie, Amy and Ma in Searching for Sylvie Lee underscore the fragmentation of the diasporic protagonists. Post-modern writing techniques, like multiple narrative, multiple voices, are preferred by many ethnic female writers, like Toni Morrison, Andrea Levy, Celeste Ng, etc. That might largely account for the fact that any single voice cannot express the oppressed diasporic females' complex and traumatic feelings. As Amy, Sylvie's younger sister in Kwok's novel, claims that diasporic women have "all facets of the same diamond" [5, p. 312]. Therefore, post-modern writing techniques go well with fractured diasporic characters.

Besides characterizing protagonists' dual personalities and writing in a discursive style, it was found that there are a number of other identical elements in Nieh's and Kwok's novels, even if their dates of publication are across nearly half a century. For instance, characters' constant spatial mobility, mental oscillations, and estrangement from their families, their motherland and even themselves. Similarly, tucked inbetween space, they are in the state of mentally unhomed. Splitting into dual personality and constituting the fluid identity are both the result of their immigrant experiences and the flexible strategy that diasporas could take to survive in the foreign land. That accidental resemblance is the grounding of comparing the two novels in this paper.

Nieh Hualing's Mulberry and Peach (Sangqing yu Taohong in Chinese) was added a subtitle, Two Women of China, when it was published in English translation version $^{1}$ [7]. The story takes the most turbulent period from the 1940s to 1970s in China as its backdrop. At that time, China was in the turmoil of the Sino-Japanese war, the civil war between the Nationalist Party and Communist Party, and the White Terror in Taiwan. The protagonist Mulberry witnessed and suffered from those wars and political persecution, and was compelled to have a miserable exiled life finally. If the first three parts of the book depict how Mulberry's personality was fragmented in the mainland and Taiwan through domestic traveling, the fourth part explicates the protagonist's dissolution and her evolution into a totally new subjectivity in transnational mobility. As many critics have pointed out, Mulberry and Peach can be considered as an allegory of modern China, which has been humiliated, trampled and segmented.

\footnotetext{
1 The publication history of Mulberry and Peach is quite complicated and arduous. Sangqing yu Taohong was first serialised in a Taiwanese magazine in the early 1970s. The novel was finally published in Hong Kong in 1976, and a second, expurgated edition appeared in Beijing in 1980. The unexpurgated version was published on the mainland in 1989. The text was translated into English in 1981 by Jane Parish Yang and Linda Lappin and published in Beijing by New World Press and in New York by Sino Publishing Company (reference to Grazia Micheli's paper "Back and Forth Between the Sea and the Mountain': Negative Mobility and Transnationalism in Hualing Nieh's Mulberry and Peach" p. 3).
} 
Serena Fusco noticed that "Nieh's novel has been repeatedly read as an allegory of the "political schizophrenia' of China in the twentieth century, divided into two distinct and antagonist political entities" [8, p. 9]. Nieh tactfully mixes personal experience with national history, and foils it with Chinese cultural heritage, like traditional paintings, historical relics and heroes, even superstitious customs on purpose. She provides a multidimensional view of China both with her splendid cultural relics and with having a period of humiliating modern history.

There're other critics taking the novel as transnational or cross-border writing. Mulberry's exile experience or escaping journey is "both an escape from intolerable circumstances and an initiation into new trauma" [9]. Fusco further argues that the novel is "a narrative of dislocation from China and attempted relocation in America", unfortunately, the protagonist's "movement from China to America as incomplete" and "an impossible translation and absorption within a 'Chinese American' identity label" [8, p. 4]. Therefore, Mulberry is always in the transnational predicament because of her "non-resolution". "The schizophrenic duplication of the protagonist's personality" is the result of her swing between "Chineseness" and "Chinese American" $[8$, p. 4]. It has grounds to conclude that Mulberry's schizophrenic is caused by her uncertainty about her identity. Admittedly, the spirit oscillations and estrangement are caused by her frequent space mobility and "non-resolution". However, there are limitations to appreciate the novel from any single dimension. From another point of view, it is also reasonable to say that the protagonist's schizophrenia or selfestrangement is both the result of her miserable mobility experiences and the tactical strategy of surviving in different spaces. Therefore, contrary to say Mulberry failed to constitute a diasporic female identity, this paper argues that mobility and estrangement facilitate the protagonist to split a new identity that is fluid, multiple and temporal and provides her the possibility to head off the danger in the unfamiliar environment. Therefore, the new-born subjectivity is the ploy for diasporic women to survive in an alien place.

Character Sylvie Lee is another Chinese diasporic woman longing for home and identity, but she was missing from the very beginning of the novel. Kwok's Searching for Sylvie Lee depicts the process of searching for Sylvie by her younger sister Amy, during which the well-kept secrets of Sylvie and her family past were unraveled bit by bit. The novel "examines the complexities of identity, culture and family as Amy struggles to understand what happened to her sister." [10] The suspense and mysterious atmosphere creation along with exquisitely psychological description coordinately claim the glamor of the novel. The secondgeneration Chinese overseas Sylvie has been brought up in the Netherlands by her aunt and grandmother. She doesn't reunite with her parents in America until she is nine years old. Even if the days in the Netherlands are namelessly oppressed, Sylvie still considers Europe as her longing place after she grows up. However, no matter living in New York or the Netherlands, Sylvie has never felt natural parental love. Instead, she always feels discarded and dislocated for all her life. Although she is independent, talented, high-achieved in Amy's eyes, Sylvie, on the contrary, is jealous of Amy's innocent, agreeable personality and the love she received from $\mathrm{Ma}$ and $\mathrm{Pa}$. The missing of such an extraordinary young lady, who gets degrees from Princeton, MIT and Harvard, has decent work and marries a rich American young guy Jim, initially seems incredible and uncanny. But as the plot develops, the other side and personality of Sylvie is unveiled. When her grandmother is dying, Sylvie lands back in the Netherlands. In the countryside of Amsterdam, her desire for relaxation, recognition and love overwhelmingly dominates her. Under the persona of an excellent lady, there is a sensitive, vulnerable and needy Sylvie. As a diaspora, even Sylvie owns double nationalities, Dutch or America, but neither of them can render her an identity. The Chinese origin is also out of reach for her. Swan Kim points out that "what continues to define diasporic existence is its feeling of powerlessness from lacking a nation-state" [11]. Travelling between Europe and America, dangling between two selves evoke Sylvie to alienate any society, family and even her self. The feeling of rootless and homeless is exacerbated when she gets to know she is a bastard. Without a lawful identity, Sylvie, which is a metaphor for diasporas who don't have a consistent and respectable identity, is doomed to struggle in the marginal space and suffer an identity crisis.

According to Jean Amato, "In the first, Chinese literary discourse around overseas Chinese diasporic texts has generally been preoccupied with themes of nostalgia, longing, and loyalty to a Chinese home-land and culture. The second direction is concerned with the study ...... of immigrant assimilation, the minority condition, and ethnic hybridity" [12]. If Mulberry and Peach concerns much about the "Chineseness" of diasporas, Searching for Sylvie Lee pays much attention to acculturation and hybridity in the more globalized world. Although the novel ends with the suicide of Sylvie, it must be admitted that Kwok has both described the psychological condition of the second generation of Chinese overseas and exemplified various ways to survive in foreign lands as diasporic females. Besides that, there are many other differences between these two novels. For instance, firstly, Mulberry and Peach contains more historical and cultural elements, while Searching for Sylvie Lee puts family issues and minority females' crisis as its priority; secondly, the 
narrative is devoid of sentimentalism in the interior monologue in the former novel, while the latter is pouring out the heart of the characters through their diaries; lastly, Searching for Sylvie Lee has more globalization tendency. It covers three continents, namely Asia, Europe, America in the narrative. In contrast, Mulberry and Peach centers in Asia and America.

To sum up, the comparison study of these two novels will undoubtedly assist in further understanding the increasing number of diasporic female group's deep psychological needs and anxieties. At the same time, the discussion on those protagonists' survival practices will also sheds light on the exploration of the possible strategies to better the minority conditions.

\section{Inextricable Predicament: Mobile and Estranged Lives of Diasporic Females}

It's noticeable that estrangement is one of the prominent motifs both in Mulberry and Peach and Searching for Sylvie Lee. Estrangement generally means "a feeling that you do not understand someone or something, or do not have any connection with him, her, or it" [13]. Both novels convey the misunderstanding and disconnection between the protagonists and their families and themselves. Meanwhile, the estrangement interplays with the protagonists' mobility or immobility.

Through spatial separation from their parents and nation, willingly or passively, both Mulberry and Sylvie experience bumpy diasporic lives. Exposed to the place dominated by the western ideology, the subordinated Asian ladies are posited in-between space, and unable to be close to or mingled themselves with neither Western nor Eastern culture successfully. "Diasporic hybridity is difficult to position themselves neither here nor there" [14]. Suffering from physical mobility and psychological oscillations ceaselessly, they go through family estrangement, self-estrangement and finally end with the split personality. Since the characters' changes and destinies are closely related to their spatial mobility experiences, it is advisable to analyze the estrangement and identity crisis and reconstitution of them from the perspective of space and mobility. This paper interprets the diasporic characters from the following three aspects: family estrangement and self-estrangement under the space and mobility theories, with the aim of exploring the inter-functions among spatial mobility, estrangement and dual personality of these two female characters.

\section{Family Estrangement}

Spatial separation may be either the cause or the result of estrangement. In some cases, leaving home indicates the dissatisfactory or disappointment of the subjectivity toward his/her family members. It is commonly accepted that "family estrangement is the loss of a previously existing relationship between family members, through physical and emotional distancing, often to the extent that there is little or no communication between the individuals involved for a prolonged period" [15]. And "emotional conflict, psychological stress, and physical abuse are aspects of these personal relationships" [16]. In other words, family estrangement is the detachment between a person and his/her family members owing to psychological alienation or bodily maltreatment or both.

Mulberry and Peach with the outset of sixteen years old Mulberry runs away from home to Chongqing with her lesbian friend, Laoshi. She leaves home because of the Sino-Japanese war apparently. But in fact, her estranged relationship with her parents is the implicit real reason of the adolescent girl plucking the courage to experience uncertain nomad life. Under the great influence of feudalism in old Chinese society, there are many unfair treatments to daughters in the family. For instance, it is commonly accepted that men have the privilege to have many wives; and only males own the right of inheritance, etc. Those are the typical presentation of patriarchal ideology in Mulberry's times. Mulberry, as the daughter in the family, often suffers biased treatment from her mother, who, however, spoils her son very much. Weirdly, Mulberry's father always puts himself out of any issue at home. The reason for the abnormal family relationship is unveiled from Laoshi's remark on Mulberry's father.

He can't even manage his own life. He lets her get away with everything while he sits in his study, the old cuckold, meditating. You call that man?... Your father wounded his 'vital part' during the campaign against the warlords [4, p.18].

In fact, the physically impotent father leads to his wife's arrogance and adultery. In this pathological family, the father converted to be the voiceless and obedient member at home, whereas the wife is in charge of everything and commits adultery with a steward. This abnormal family and conjugal relationship are completely different from traditional family in the patriarchal society, which partially implies the reversal of the values of family and traditions. Most importantly, it makes Mulberry feel unloved, suffocated and humiliated.

Besides the abnormal family atmosphere, unfair treatment and abuse enhance Mulberry's determination to leave home. There is a family heirloom, jade griffin, which is passed down for many generations to Mulberry's father. And the father puts it in his pocket and always caresses it. It is said the griffin could "scare away devils" [4, p. 18]. It is supposed to pass down to Mulberry's brother, but her greedy mother takes it away instead. Little Mulberry has once tried to touch it, but she broke one wing of jade griffin by accident, which irritated her mother and she was 
confined at the dark attic as punishment. Both out of reach of the heirloom and placed in the isolated attic indicate that the mother intentionally distances her from inheritance and other family members. Always getting abusive treatments, helpless Mulberry decides to leave her indifferent parents and escape from her family.

On the way of running away, Mulberry hesitates whether she was right or not to leave home in this way. Laoshi confirms Mulberry that "your mother will kill you if you go back", and reminds her, that "when your mother was drunk, she would beat you for no reason, until you bled" [4, p. 18]. Obviously, neither Mulberry's cruelhearted mother nor her impotent father could extend family love to Mulberry. That makes her estrange from them and be determined to escape from the callous family.

Mulberry's family is no longer a place of peace, comfort and warmth but a location of turmoil, alienation and violence. In a sense, the abnormal family of Mulberry symbolizes disordered China in the alternating times when decadent feudalism meets liberation and equality ideology. As an allegory story, if Mulberry's father symbolizes feudalism in China in wars, griffin probably can be seen as the soul of the nation, which is the extraction from history and cultural treasures. And the mother is the invader who deprives the soul of the weak and impotent nation. The separation between the father and the griffin indicates the estrangement between the nation and her soul or spiritual treasures. Furthermore, the cracked griffin unveils the torn apart country in the 1940s. It is noticeable that Nieh tactfully connects the national fragmentation situation with family estrangement fate.

Similarly, Sylvie's family also can not belong to normal ones. The strange husband and wife relationship is indicated at the very beginning of the novel. The first plot is that Amy, the younger sister of Sylvie, is peeping at her parents leaving for work from the window:

"At the entrance, they pause and look at each other for a moment. Here, I always hold my breath, waiting for Pa to touch Ma's cheek, or for Ma to burst into tears, or for either of them to give some small sign of the truth of their relationship. Instead, Ma raises her hand in an awkward wave, the drape of her black shawl exposing her slender forearm, and $\mathrm{Pa}$ shuffles into the open mouth of the station as the morning traffic roars down out busy street" [5, p. 3].

Undoubtedly, there is something intangible between $\mathrm{Ma}$ and $\mathrm{Pa}$. What is hidden underneath their relationship? And why Ma acts awkwardly instead of intimately in front of her husband? Their repressed love and the unexpressive pain are disclosed through their restrained actions or expressions quietly. "Sometimes I (Amy) spot a look that might be longing on his (Pa's) face but then I blink and it's gone, as if it had never existed" [5, p. 31]. The atmosphere of oppression and hesitancy pervades the whole story. Lack of communication shows the uncanny and estranged relationship between $\mathrm{Ma}$ and $\mathrm{Pa}$.

As the plot develops, the secrets of the parents and Sylvie are exposed gradually. Sylvie has been brought up by Ma's cousin Helena in the Netherlands since she was an infant. Growing up in an alien land with relatives instead of her parents makes Sylvie sense the displacement. Moreover, Helena's inexplicable dislike or sometimes even hatred is the nightmare in Sylvie's childhood. When she was at her early age of needing care and love, Sylvie received indifference and coldness. In her diary, she wrote, "when I was little, how many times did I daydream of Helena hugging me, telling me I had done something wonderful" [5, p. 155]. And "despite my fear of Helena, I still loved her and tried my hardest to please her" [5, p. 267]. Naturally, children long for recognition from their care-takers. Helena plays a mother role in little Sylvie's mind. She desires Helena's appreciation and affirmation. It is irreplaceable to grant children a sense of safety and love in their childhood, which is vital for them to establish a healthy personality in their later life. However, aunt Helena treats her as an outsider and tries every means to erase and estrange little Sylvie. When she returns back to the Netherlands more than twenty years later, she notices that "there was not a single photo of her. She had been erased as if she had never existed" in the house [5, p. 71]. Years passed, but the unaccountable hatred from Helena still makes Sylvie hurt as before. She longs for the motherly love from Helena, but no matter what she achieved she can't make Helena accept her. The traumatic childhood experience makes her personality begin to become strange and deformed. She finally turns her longing for love into revenge. Through studying and working extremely hard, Sylvie yearns to become "an equal adversary to Helena" [5, p. 72]. That motivation further isolates her from her Netherlands family members and seals her fate of estrangement.

At the age of nine, Sylvie is brought back to America by Ma. But the reunion also means separation for her, since she has already set a kind of connection with people and things in the Netherlands. Pitifully, living with $\mathrm{Ma}$ and $\mathrm{Pa}$ in America doesn't allow Sylvie to enjoy the dreamed parental love.

That is partly because of Helena's malicious words. Helena's farewell words always linger around Sylvie's mind. "They only need a childminder for their new daughter" [5, pp. 39-40]. Her vicious warning smashes the young girl's hope of getting acceptance and love from her parents and makes her posit herself in the place of margin or affiliation in the family. When she meets her mother after nine years' departure, Sylvie feels "she was the mother I had yearned for, but my heart had no more room for her. It had been too late" $[5$, p. 61]. The nine years' separation between mother and daughter seems irretrievable. Their psychological 
distance just likes the geographical distance, as far as the ocean extends.

In addition, the strange relationship between $\mathrm{Ma}$ and $\mathrm{Pa}$ creates an atmosphere of oppression and suffocation in the family. That also accounts for her isolation from them. When Sylvie is young, she often witnesses an abusive father and a submissive mother in their constant fights.

Those horrible fights they'd had when we were little, when Pa would get drunk and call Ma a whore and a liar. But still, there was tenderness when they looked at each other, though it was quickly hidden away again. Ma stayed up late mending Pa's work gloves. $\mathrm{Pa}$ put the choicest pieces of abalone in Ma's rice bowl. An ocean of love, guilt, and duty surged back and forth between them, stroking both their hearts even as it kept them apart [5, p. 152].

From the lines above, it can be seen that the mixture of love and hatred is not only in the mind of Sylvie toward Helena, but also in the relationship between $\mathrm{Ma}$ and $\mathrm{Pa}$. Undoubtedly, the domestic abuse leaves a shadow on the two young daughters, especially to the former traumatic child Sylvie. She is disappointed once more about the family through observing the horrible fights between $\mathrm{Ma}$ and $\mathrm{Pa}$, which further pushes her out of the home.

Separated from her mother as an infant, living with a vengeful and hard-pleasing aunt for nine years, and then reuniting with her uncanny parents, Sylvie suffers from estrangement both in the Netherlands and in America. She has to go beyond one place after another. For Sylvie, displacement is her life melody. Whatever she strives, she can't go out of the interstice. The sense of needlessness and outsiders always hovers over her mind. The most desperate thing is that she is unable to figure out the reason why she is disliked by her family members. Lack of communication among her family members probably accounts for the strange family atmosphere. The conservative and repressive feelings are confined in their hearts for so many years that they unintentionally hurt their loving ones. Finally, Sylvie is estranged from her family completely. The feelings of marginalized and discarded encourage Sylvie to transform her love toward Helena and $\mathrm{Ma}$ to the drive of gaining recognition and affirmation from others. She tries every means to cater to the standards of the society, through which she losses her instinct joy and self, and isolates herself. Family estrangement not only discourages the communication between Sylvie and her family members, but also distorts her personality to some degree.

At the end of the novel, the whole family gathers together, and Ma finally discloses the real reason of strangeness in the family. In fact, Sylvie is the daughter of Ma and William (Helena's husband), that's why Helena hates her and Pa can't accept her. To be taken as a punished substitute, Sylvie experiences the alienated, bias even hatred both in the Netherlands and in America's homes, which causes her "a vertiginous unbalancing of life and self" [17]. The strange familial environment makes Sylvie lack self-assurance and self-efficacy during her childhood and adolescence, which prevents her from having a healthy personality.

If the mobility life of Mulberry is caused by family estrangement, Sylvie's family estrangement is produced by spatial mobility. Thus, spatial mobility and family estrangement are reciprocal cause and effect. Despite the differences in the causes, both protagonists estrange themselves from their families and embark a life of mobility. The psychological distance is much farther than the geographical spatial distance. And the former one sometimes can't overcome, and it may further bring other miserable consequences.

\section{Self-estrangement}

The restricted gendered and social role, combined with uncertainties about their ability and potential; and skepticism about individual's engagement in activities would rewarding in themselves indeed result in the self-estrangement of diasporas. More specifically, the self-estranged people have a low level of self-esteem or fail in getting the sense of self-realization. They are unable to enjoy the intrinsic reward through the work or tasks they undertake. This may lead the self-estranged individual to suffer from identity confusion or form a "bad faith" with oneself.

Self-estrangement often happens in the initial stage of schizophrenia. Many Asian diasporic females, no matter decades years ago or contemporary, have experienced self-doubt and self-denial owing to the patriarchal society and Euro-centric ideology to a large extent. In that kind of social space, their abilities, thoughts and needs are being neglected or disavowed. The initial desires and values of females are distorted by the infused powerful and deep-rooted ideology. That causes their mental immobility and frustration. Gradually, the longterm self-abasement evolves into the self-estrangement and mental oscillations of expatriated women.

Both Mulberry and Sylvie experience self-estrangement and suffer from insomnia and schizophrenia. The third part of Mulberry and Peach describes the exile experience of Mulberry with her husband Chia-kang and their daughter Sang-wa in Taiwan because Chia-kang has embezzled public money and is

\footnotetext{
${ }^{1}$ KMT stands for Kuo Min Tang, also translated as "Chinese Nationalist Party". It is a Chinese political party founded by Sun Yat-sen. KMT is the first bourgeois political party in the history of China and one of the oldest political parties in the Republic of China and Asia. After losing the civil war between the KMT and the Communist Party in 1949, KMT evacuated from mainland to island of Taiwan. It is now a political party in Taiwan.
} 
hunted by $\mathrm{KMT}^{1}[18]$. Mulberry once again resumes her exile life, fleeing from Peking to Taiwan. Her mobility is always with immobility paradoxically. Arriving in Taiwan, she and her family are confined in an attic for ten years. The unhuman attic life makes Chiakang impotent and nearly paralyzed. Sang-wa can't speak or walk like a normal child and Mulberry shows the signs of self-estrangement initially. Each of them is confined in their tatami mat in the attic. They seldom move and don't speak to each other, experiencing physical and mental deteriorating day by day.

In the attic, "the sense of oppression within a tight and isolated space and the resulting sense of alienation further exacerbated by the prohibition to communicate or move freely" $[1$, p. 6]. Grazia emphasizes that "although images of confinement, imprisonment and immobility seem to conflict with Mulberry and Peach's endless relocations, both mobility and immobility constitute a form of oppression and a cause of suffering" [1, p. 9]. Whether Mulberry is in a state of mobility or immobility, she suffers oppression and alienation. That is because her spatial movement is compelled but not out of her own will.

Mulberry once consoles her young daughter that, "The earth is a huge attic. The huge attic is divided into millions of little attics, just like ours. She wants Sangwa to understand that the other people in this world live just like them" [4, p. 129]. Freedom for everyone is limited. At this time, Mulberry seems to accustom to the life in the enclosed space, but she feels suffocated, fearful and anxious. Isolated in the small and dark attic, Mulberry refects "all greed, anger, craving and love disappear" [4, p. 139]. She is independent of, or estranged from her instinct feelings and desires.

However, the illness of the wife of Mr. Ts'ai, who allows Mulberry and her family to hide in his attic, is a turning point for Mulberry's life. She determines to take care of aunt Ts'ai in return to their help for so many years. Mulberry begins going out of the attic, and crossing the borders time and again. She goes downstairs to the door, then out the door, then into the yard. Finally, she walks down the road at night, passes the intersection, drug store, newspaper stand, airline office... and arrives at the hospital that aunt Ts'ai stays. Crossing borders or going beyond is a valiant behavior that could even instigate social change, and it's a way to the open and limitless Thirdspace. In accordance with Bhabha's opinion, going beyond leads to a promising and unknowable future. And the unpredictable coming future tempts Mulberry to pass the border and come to a new place. At that place, "her life splits in half. Daytime in the attic. Night-time at the hospital" [4, p. 141]. The split happens not only in her shifts of attic and hospital but also in her psychology.
Regaining freedom of movement, Mulberry also liberalizes her spirit. Finally, she has an intimate relationship with Mr. Ts'ai and becomes his mistress after the death of aunt Ts'ai. Mulberry then tries every way to "live a normal life", and lets Mr. Ts'ai's friends call her "an innocent criminal" [4, p. 144]. The appellation is in accordance with what aunt Shen unconsciously uttered: "Your eyes are too watery. You're a girl who dreams wild and ridiculous dreams. You try to seem clean and pure, but in your heart, you're like a snake or a scorpion. You're the kind of girl who could even fantasize about your own father. You're an evil star - a jinx on your father, mother, husband and sons!" [4, p. 87].

Mulberry internalizes the imposed vicious identity and encourages others to see her as a guilty woman but with an innocent aspect. The conflicting power begins to struggle inside Mulberry. The new agent starts to generate after her going beyond borders. It's natural that people want to recover from or conquer such feelings of confinements, isolation and estrangement. Admittedly, Mulberry utilizes Mr. Ts'ai to help her step out of the attic and regain freedom. She detaches from the traditional gender role. Whether she is innocent or criminal, Mulberry starts a completely different life after all. In this process, the other agency of her, a wild dark one, starts splitting from her whole self imperceptibly.

In the novel Searching for Sylvie Lee, Sylvie is a successful young lady in America. It seems she owns freedom and can deal with anything, like "a female James Bond" [5, p. 15]. Her excellent school work, successful career and admiring marriage make her younger sister Amy pale by comparison.

"Sylvie went to Princeton undergrad, earned a master's in chemical engineering from MIT, worked a few years, then went back to school for her MBA from Harvard. Now she's a management consultant, which is a profession I'll never understand no matter how many times she tries to explain it" [5, p. 5].

After graduating from university, Sylvie married her schoolmate Jim, who is from an extremely rich American family. Astonishingly, Sylvie, the favorite of fortune, is mysteriously missing. Actually, nine-year foster care life leaves Sylvie with great trauma. She is a self-depreciation and self-denial woman under her perfect persona ${ }^{1}$ [19]. She always strives to do everything to please others whom she loves. She imagines, in that way, she may get love, affection and recognition from them. However, as she practices her catering life, she is losing herself.

Leaving and returning between America and the Netherlands seems to split Sylvie into two pieces. Each departure means the separation from a part of

${ }^{1}$ The persona, for Swiss psychiatrist Carl Jung, was the social face the individual presented to the world_-"a kind of mask, designed on the one hand to make a definite impression upon others, and on the other to conceal the true nature of the individual". 
herself. At nine years old, "she had taken the hand of a woman she did not know and walked away with her to start a new life" [5, p. 61]. Ma loves her but she can't extend her love to reach the inner heart of her daughter after a long time separation.

"Sylvie had lost the baby's loveliness. Her lazy eye, her bent tooth, and that haunted look make her too intense and foreign for the tastes of the Beautiful Country. When I tried to make up for the years I had not been able to hold her, her body stiffened and pulled away, scrambling to get as far away from me as she could" $[5$, p. 74$]$.

Ma notices that "she left the girl as Sally and returned as Sylvie" [5, p. 13], because Holland people don't recognize the name Sally given by Ma in America. In the Netherlands, she gets her new name Sylvie. As the changes of the name, the personality of Sylvie also undertakes transformation. In addition, the deformed physical features of the crooked tooth and slightly shifting outward right eye further unveil the twist and estrangement of Sylvie. Gradually, she turns her anguish and desires to study and work diligently in order to get recognition from others for her excellent performance at school and workplace.

Marrying an American young man Jim seems to realize her long-lasting dream of being accepted and loved. Gaining Jim's love not only confirms Sylvie that she is attractive to males but also welcomed by this Beautiful Country. It is also a symbol that she is accepted in the American social space. She gets some comfort and consolation until she finds out about Jim's affair with his teenage student. When Sylvie recalls their relationship, "she was not sure if they had truly loved each other or merely the versions of themselves they had seen reflected in the other's eyes" [5, p. 23]. Although met such a disastrous issue in marriage, Sylvie has never disclosed it to her family or any friend. As an immigrant, Sylvie was infused by elders that they, as diasporas, should keep secrets and disguise themselves. She recorded it in her diary as follows.

"Helena, my own ma and pa: They taught us to keep our heads low, to hold our secrets as close as an oyster. Keep ourselves apart from everyone else. At a certain point, you wind up dividing yourself internally into so many different people you do not even know who you are anymore" [5, p. 159].

The customary silence and self-estrangement even make her lose the ability to ask for help when she met difficulties. Evidently, the long-term constrained state of diasporas makes her depressed, anxious and helpless. Finally, Sylvie flies to the Netherlands since partly grandma is seriously sick, partly she wants to recover from the trauma caused by betrayer Jim, and most of all, she hopes to gather back the left part of herself. In front of the plight, Sylvie intends to recover from and solve it through a changing environment or space. In the privacy of her thoughts, the Netherlands is her real home, as Ma reflected that "Sylvie left a piece of her spirit behind in Holland" [5, p. 73]. She feels relaxed and joyful at the moment she arrives in the Netherlands.

"God, I was glad to get away from everything. We exited the plane and I quickly strode through the airport. My soul leaped as if it had been freed of its bindings. I had left the jungle of New York City and was back in the warm and welcoming plains" [5, p. 63]

Since Sylvie grew up in the Netherlands, she has emotional dependence and attachment to it. Sylvie, at this moment, imagines the Netherlands is her homeland and shelter, where she could collect the fragmented self. "Diasporas use the homeland as a source of cultural sustenance and pride, a kind of cultural refueling depot" [20] as well as identity constitution resources. Arriving at the imagined homeland makes Sylvie obtain the sense of belonging. Nonetheless, it is not long that she realizes that "I was terrified that my dream of the one place I truly belonged would be overwritten and I would have nothing left, no solace at all" [5, p. 40]. The hostile reception of Helena exacerbates that Sylvie is an outsider and unwelcome person, which worsens her self-estranged sentiment. "I always try so hard and yet, it all goes wrong. No one really likes me. Not after they know me, anyway." [5, p. 285]

As Mulberry took advantage of men to get out of trouble, Sylvie turns to establish a relationship with different males to prove her existence and self-value. Sexual transgression is a kind of resistance to the unfair treatment of females in the social space. Both Mulberry and Sylvie experience an unhappy marriage. They are disappointed about marriage and males. Then they intend to rebuild or reverse the relationship between male and female. Instead of being accessories to men, they use their body to attract males, and further realize their aims. If Mulberry made use of males to get "freedom", Sylvie wants to come through difficulties with them.

In this stage, Sylvie's cousin Lukas provides her great consolation. The sensual touches, tacit understanding and common childhood experiences between them make Sylvie hope to reconstruct herself through the connection with Lukas.

"Here I was with Lukas, who had known and loved me before I became somebody and before I lost it all too. Being with him was as natural as breathing. My cousin, my friend" [5, p. 86].

Besides grandma, Lukas is another important person in Sylvie's life. Sylvie is always aware of her changes. She acknowledges that there is a true self and a "transformed" one. Lukas is one of the few who knew her before she "become somebody" else. He often assures Sylvie that "You are no stranger." [5, p. 86] and "I am in love with imperfection. [5, p. 88] after 
Sylvie's coming back to the Netherlands. Gradually, the relationship between the cousins grows intimate. To find a person who understands her, accepts her with her original self, shares with her the same painful experience as diasporas, is what Sylvie desperately needs. The unconditional love and the sense of security given by Lukas soothe Sylvie greatly. Lukas is finally taken as the only reason that she could remain in this world after the death of her grandma. And she even gains the hope and courage toward life for the moment. However, when she suddenly knows they are not remote cousins but brother and sister by the same father and different mothers, the last straw breaks Sylvie into pieces. She has no strength to confront the ruthless fact but ends her life bearing this in her mind, "Deep down, I had known true love was not for me" [5, p. 197].

After Sylvie's missing, Amy reports it to the police. But she even meets some difficulties when she provides the identity of Sylvie to the policeman in the Netherlands.

"You are from the United States? And Sylvie Lee, she is also American?"

I say, "Yes," at the same time Lukas says, "No, she is Dutch."

Then Helena smiles and says, "She is Chinese," as if that settles the matter.

William says, "Sylvie had dual Dutch American nationality." [5, p. 97]

In different people's eyes, Sylvie is a different person. But no one can have a full view of this diasporic lady. At the same time, her relative's inconsistent answers about her identity further indicate the awkward situation of immigrants and provoke them to reconsider who she is and, most importantly, who they are. Like the dual nationalities Sylvie has, she can't reconcile the two selves within herself and fails to find out who she really is, where she truly belongs. No matter how many nationalities she has, she's unable to find her location in the whole world. In the desperation of love and not, Sylvie steps far on the road of self-estrangement, which finally causes her miserable fate.

It can be seen that the mobility lives, the indifference of their families and the prejudice in the cultural and social space lead the diasporic ladies, Sylvie and Mulberry, to self-estrangement, schizophrenia even suicide tragedy. Estrangement and cross-border mobility interact, as both cause and effect, with each other. However, the resiliency of the human spirit plays a great role while they were dislocated in the marginal space. As Bell Hooks argues, "these margins have been both sites of repression and sites of resistance", because "it nourishes one's capacity to resist. It offers the possibility of radical perspectives from which to see and create, to imagine alternatives, new worlds"
[21]. In fact, Mulberry and Sylvie both try to recover from the predicament through cross-border movements, establishing a relationship with males, even constituting another personality. Only in this condition can people be stimulated the potential of survival in such marginal space.

\section{Conclusion}

In the form of allegory, Mulberry and Peach describes the plight of China in the latter part of the twentieth century, while with the backdrop of contemporary, Searching for Sylvie Lee presents the transnational experiences of Chinese females in the twentyfirst century. Nieh and Kwok both depict the physical immobility and mental oscillations of exile female characters in their novels. But no matter where they are, they often disclose their reminiscence to China, their attachment to the Central Kingdom. As diasporic females, both authors advocate a healthier relationship in the family, an understanding of ethnic relationships and the imagination of a cosmopolitan world. Unfortunately, Mulberry and Peach are actually "stateless - a wanderer cut off from homeland, family, and community" [22]. Identically, Amy reflects that "my sister the woman without a country" [5, p. 312-313]. Undeniably, Mulberry and Sylvie commonly suffer the "high coefficient of deterritorialization" and they can't be accepted by any country. Constituting a paradigmatic and static diaspora female identity just like the prince bird picking stones to fill the sea in the episode of Mulberry and Peach, who is painstakingly and stubbornly persistently doing an elusive and unrequited thing. The miserable experiences prompt the protagonists to estrange themselves from their family and self.

Dislocated in America or Europe, they always live on cultural or social margins or in-between space. Their resilient human spirit helps them to adjust to the new place, culture and environment. Spatial mobility and estrangement interplay between each other, finally leading to their dual personalities, which, paradoxically, can be seen as both the predicament and the survival strategies of the diasporic females. That is to say, the fictional protagonists show the possibilities that constant mobility would bring about flexibility, fluid identity. It is a request for survival in the hyper-connected world. Everyone is involved in integrative development. It is unwise to adhere to a single culture as diasporas but constitute an open-minded and hybrid identity in-between space. Cultural hybridity and self-appreciation can be taken as the strategies for actively adapting to the changes in their mobility lives. Mulberry and Sylvie show their dual personalities and fluid identity in diverse circumstances, just like diamond having different facets. 


\section{References}

1. Micheli G. Back and Forth Between the Sea and the Mountain: Negative Mobility and Transnationalism in Hualing Nieh's Mulberry and Peach. Transatlantica: Revue d'Études Américaines. 2019, no. 9, pp. 1-17.

2. Wong Sau-ling C. Reading Asian American Literature: From Necessity to Extravagance. Princeto: Princeton University Press, 1993.

3. Schiller N. G. From Immigrant to Transmigrant: Theorizing Transnational Migration. Anthropological Quarterly. 1995, no. 1, p. 48.

4. Hualing N. Mulberry and Peach: Two Women of China. 1976. New York, The Feminist Press, 1998.

5. Kwok J. Searching for Sylvie Lee: A Novel. New York, William Morrow, 2019.

6. URL: https://www.poetryfoundation.org/poets/paul-engle (URL: 27 November 2020).

7. Micheli G. Back and Forth Between the Sea and the Mountain: Negative Mobility and Transnationalism in Hualing Nieh's Mulberry and Peach. Transatlantica: Revue d'Études Américaines. 2019, no. 9, pp. 1-17.

8. Fusco S. Call Me an Innocent Criminal: Dual Discourse, Gender, and "Chinese" America in Nie Hualing's Mulberry and Peach. Journal of Transnational American Studies. 2012, no. 4, pp. 1-17.

9. Chiu Ma. Trauma and Multiplicity in Nieh's Mulberry and Peach. Mosaic. 2003, no. 3, p. 21.

10. URL: https://www.jeankwok.com/ (accessed 27 November 2020).

11. Kim Swan. "Beyond Allegory: Absurdity, Paranoia, and the Diasporic Identity in Hualing Nieh's Mulberry and Peach: Two Women of China". Pennsylvania Literary Journal. 2017, no. 9, pp. 71-90.

12. Amato J. "Relocating Notions of National and Ethnic Authenticity in Chinese American and Chinese Literary Theory Through Nieh Hualing's Overseas Chinese Novel. Mulberry and Peach". Pacific Coast Philology, 1999, no. 1, pp. 32-52.

13. URL: https://dictionary.cambridge.org/dictionary/english/estrangement (accessed 27 November 2020).

14. Sun Teh Chiao. Diaspora, Hybridity and the Root of Identity: Zadie Smith's White Teeth and Kiran Desai's The Inheritance of Loss, Diss. of Sungkyunkwan University, 2018.

15. URL: https://en.wikipedia.org/wiki/Family_estrangement (accessed 27 November 2020).

16. Theone J. A Study of the Theme of Estrangement in the works of Anne Hebert, Diss. of University of Montana, 1979.

17. Roberson S. Narratives of Relocation and Dislocation: An Introduction. Women, America, and Movement: Narratives of Relocation. Columbia: University of Missouri Press, 1998, pp. 1-15.

18. URL: https://baike.so.com/doc/2371969-2508004.html (in Chinese) (accessed 27 November 2020).

19. The Collected Works of C. G. Jung, Complete Digital Edition, 19 volumes, ed. Gerhard Adler and R. F. C. Hull. Princeton, NJ: Princeton University Press, 2014, p. 305.

20. Addis Adeno. Imagining the Homeland from Afar: Community and Peoplehood in the Age of the Diaspora. Vanderbilt Journal of Transnational, 2012, no. 45, pp. 963-1041.

21. Hooks B. Yearning: Race, Gender, and Cultural Politics. Boston, MA: South End Press, 1990.

22. Wong Sau-ling C. Afterword to Mulberry and Peach: Two women of China. New York, The Feminist Press, 1998, pp. 209-230.

Zhao Dongxu, Jilin Institute of Chemical Technology, China, MA, Assistant Professor (132022, Jilin City, Longtan District Chengde Street 45).

E-mail: anquanf@hotmail.com

Материал поступил в редакциюю 31.08.2020.

DOI 10.23951/1609-624X-2021-3-135-145

\section{ПРОСТРАНСТВЕННЫЙ ПОТОК И ДУХОВНОЕ ПОТРЯСЕНИЕ: ОТЧУЖДЕНИЕ ЖЕНЩИН В ИММИГРАЦИИ В РОМАНАХ «САНЧИН И ТАОХУН» И «ИСКАНИЕ ЛИ ЭРВЭЙ»}

Чэнао Дунсю

Цзилиньский химико-технологический институт, Цзилинь, Китай

Введение. Изучаются проблемы осознания жизненных трудностей, психологических потребностей и тревоги женщин азиатской диаспоры, а также их стратегии выживания.

Методы исследования. Используется метод сравнительного анализа литературы и мотивного анализа.

Результаты и обсуждение. Интерпретируются два романа, написанные китайскими писательницами, живущими за пределами Китая. В произведениях «Санчин и Таохун» (автор Не Хуалин) и «Искание Ли Эрвэй» (автор Го Фанчжэнь) описывается диаспорический опыт героинь в периоды войны и мира. Несмотря на то, что публикации этих двух романов разделяет почти полвека, в них присутствует множество похожих элементов. Обе геро- 
ини пережили постоянную трансграничную мобильность, отчуждение и даже шизофрению. Исследуются три аспекта: во-первых, почему женщины диаспоры ощущают себя отчужденными; во-вторых, прослеживается диалектическая связь между пространственной мобильностью и отчуждением; в-третьих, как и почему у них формируется раздвоение личности и мобильная идентичность.

Заключение. Частая пространственная мобильность побуждает женщин диаспоры отчуждать себя от своих семей, национальной культуры и даже самих себя; сочетание пространственной мобильности и отчуждения ведет к раздвоению личности таких женщин, которое не только обусловлено их тяжелым положением, но также может рассматриваться как некая стратегия выживания.

Ключевые слова: отчужденность, женщины, эмиграция, пространственный поток.

Чжао Дунсю, доктор, доцент, Институт Цзилиня химической технологии (район Лонтан, ул. Ченьдэ, Цзилин, Китай, 130022).

E-mail: anquanf@hotmail.com 